\title{
Analisis Prospek Penerimaan Pajak Bumi dan Bangunan Di Kecamatan Asparaga Kabupaten Gorontalo
}

\author{
Samin Taliki \\ Sekretaris Desa Bululi, Kecamatan Asparaga, Kabupaten Gorontalo \\ email : samintaliki@gmail.com
}

\begin{abstract}
Gorontalo Province is still one of the newly developed areas that always expect the participation and support from various parties, both morally and spiritually in the form of facility improvement and human resource formation must be developed simultaneously, it is clear that this will encourage economic development for the society as a whole. This study aims to analyze the Prospect of Receipt of Land and Building Tax in District of Asparaga Gorontalo Regency. The main variables used are land tax and building. The analysis method used is Linear Trend analysis. The results showed that the Linear Trend is $Y=900343714,60+5006432,80 X$ which means the variable of the earth and building taxes have good prospects in the District Asparaga. And with the value of linear trend can be calculated the estimated value of land and building tax revenue for the period 2017-2021 in District Asparaga.
\end{abstract}

Keywords : land and building taxes, prospects

\section{PENDAHULUAN}

Pembangunan ekonomi merupakan salah satu strategi yang dilakukan oleh pemerintah pada setiap tahun dalam rangka meningkatkan percepatan proses perubahan struktural ekonomi masyarakat dengan penjabarannya pada bentuk kegiatan yang langsung kepada masyarakat agar tercipta masyarakat adil dan makmur berlandaskan pada asas Pancasila dan Undang Undang Dasar 1945.

Untuk itu, Sebagai konsekuensi dari pelaksanaan pembangunan nasional yang harus membawa perubahan pada berbagai sektor ekonomi produktif pada peningkatan output yang terjadi pada berbagai rumah tangga dalam suatu perekonomian bangsa maka perlu upaya peningkatannya secara terus menerus serta jumlahnya juga harus ditingkatkan. Hal ini dapat tercapai dengan menjalankan berbagai pola pengembangan baik mulai dari tradisional sampai pada proses pengolahan secara modern dengan teknologi yang disesuaikan dengan kondisi daerah masing-masing.

Dengan demikian kita tetap menyadari bahwa proses percepatan pembangunan yang menitikberatkan pada laju pertumbuhan ekonomi yang tinggi harus disertai dengan pemerataan pendapatan masyarakat sehingga 
bentuk perubahan pola kehidupan lebih terdorong bagi proses kegiatan pembangunan ekonomi rakyat pada berbagai strata kehidupan masyarakat.

Untuk itu dalam upaya mempercepat proses pengembangan daerah model seperti tersebut harus terus berkembang di masyarakat Provinsi Gorontalo walaupun masih merupakan salah satu daerah yang baru berkembang yang tentunya selalu mengharapkan pastisipasi dan dukungan dari berbagai pihak baik sifatnya moril maupun spritual berupa peningkatan fasilitas dan pembentukan sumberdaya manusia harus berkembang secara bersamaan maka jelas hal ini akan mendorong meningkatkan pembangunan ekonomi bagi masyarakat secara keseluruhan.

Sehubungan dengan itu, peningkatan pembangunan tentunya membutuhkan tidak sedikit anggaran pemerintah yang dibutuhkan pada setiap tahun, makanya kalau berkembang idealisme masyarakat dalam peningkatan output total maka jelas hal ini akan memberikan kontribusi langsung pada kemampuan masyarakat dalam membayar berbagai kewajiban mereka berupa pajak maupun kewajiban lainnya yang menjadi sumber penerimaan pemerintah akan lebih meningkat sehingga penbentukan anggaran untuk pembangunan pada setiap tahunnya pasti semakin baik guna untuk melaksanakan berbagai program dalam meningkatkan kesejahtraan masyarakat pada umumnya dapat tercapai secara maksimum.

Demikian pula dengan Pemerintah Kabupaten Gorontalo yang memiliki kemampuan untuk menggerakkan dan memotivasi masyarakat pada setiap wilayah kecamatan selalu memberikan pemahaman dan kesadaran bagi para wajib pajak dalam upaya peningkatan penerimaan daerah berupa pajak yang dapat meningkatkan serta memperbesar target yang diharapkan pada setiap tahunnya, mengingat tuntutan pembangunan yang diprogramkan setiap tahunnya pula harus direalisasikan kepada kepentingan masyarakat dengan tujuan untuk dapat mendorong berkembangnya kegiatan ekonomi masyarakat sehingga pertumbuhan ekonomi yang dapat tercapai berdasarkan rencana yang ditetapkan setiap tahunnya.

Dalam upaya meningkatkan percepatan proses pembangunan pada berbagai bidang haruslah ditingkatkan pula pendapatan dari berbagai pihak yang berasal dari penerimaan pajak bumi dan bangunan pada setiap tahunnya sehingga akan mempengaruhi peningkatan pendapatan daerah itu sendiri pada setiap tahun tertentu. Dengan meningkatnya pendapatan Daerah tersebut kegiatan pemerintah pula dalam pembangunan semakin meningkatkan sehingga usaha dalam penciptaan kesejahtraan masyarakat terus ditingkatkan.

Untuk itu dengan terciptanya peluang peningkatan kesejahtraan masyarakat semakin meningkat dapat menggambarkan kemampuan bagi setiap anggota masyarakat didaerah tersebut dalam memenuhi berbagai kewajiban yang melekat pada setiap warga negara, misalnya dapat membayar berbagai jenis pajak serta kewajiban lainnya yang dapat merangsang pendapatan bagi daerah tertentu akan semakin baik sehingga akan membantu untuk merealisasikan segala kepentingan serta kebutuhan masyarakat secara kentinue dimasa depan.

Dengan memperhatikan Kecamatan Asparaga merupakan salah satu kecamatan yang paling ujung bagian barat Kabupaten Gorontalo tetapi seluruh masyarakat sangat antusias terhadap upaya pemerintah sekarang ini telah banyak memperhatikan dukungan pembangunan berupa peningkatan fasilitas pembangunan jalan, pendidikan dan lain sebagainya. Untuk itu 
masyarakat Kecamatan Asparaga lebih memperhatikan pula berbagai kewajiban mereka sebagai warga negara yakni taat dan wajib membayar pajak Bumi dan Bangunan pada setiap tahunnya.

Untuk itu, dari sekian banyak kewajiban mereka tersebut maka yang paling penting adalah pembayaran pajak tersebut sehingga sekian penduduk yang kena wajib pajak maka lebih jauh lagi perlu dikaji dan dievaluasi apakah jumlah penerimaannya pada setiap tahunnya akan tetap memberikan prospeknya kedepan terutama pada jumlah yang diterima oleh pemerintah Kecamatan Asparaga demi terciptanya proses kegiatan pembangunan ekonomi pada seluruh lapisan masyarakat ditahun akan datang pula.

Dari uraian diatas peneliti memfokuskan masalah penelitian dalam menganalisis tentang hal-hal yang berhubungan dengan penerimaan pajak setiap tahun dengan diberi tema : "Analisis Prospek Penerimaan Pajak Bumi dan Bangunan di Kecamatan Asparaga Kabupaten Gorontalo"

\subsection{Konsep Pajak}

\section{TINJAUAN PUSTAKA}

Menurut Mardiasmo (2011 : 1) mengatakan pajak adalah iuran rakyat kepada kas Negara berdasarkan Undang-Undang (yang dapat dipaksakan) dengan tiada mendapat balas jasa timbale (kontraprestasi) yang langsung dapat ditunjukkan dan yang digunakan untuk menbayar pengeluaran umum.

\subsection{Jenis-Jenis Pajak}

Sebagaimana telah disampaikan dalam Pasal 2 ayat (1) Undang-Undang Nomor 34 Tahun 2000 Tentang Perubahan atas Undang-Undang Nomor 18 Tahun 1997 Tentang Pajak Daerah dan Retribusi Daerah; diatur mengenai jenis Pajak Provinsi sebagai berikut :

1. Pajak Kenderaan Bermotor ( PKB ), .

2. Pajak Kenderaan Bermotor Di Atas Air ( PKBDA ),

3. Bea Balik Nama Kenderaan Bermotor ( BBNKB ),

4. Bea Balik Nama Kenderaan Bermotor Diatasa Air ( BBNKBDA),

5. Pajak Bahan Bakar Kenderaan Bermotor ( PBBKB );

6. Pajak Pengambilan dan Pemanfaatan Ari Bawah Tanah ( P3ABT );

7. Pajak Pengambilan dan Pemanfaatan Air permukaan ( P2AP) ;

Menurut Waluyo (2012 : 12) pajak dapat digolongkan kedalam 3 kelompok besar adalah sebagai berikut :

1. Menurut penggolongan atau pembebanan dibagi menjadi berikut ini :

a.Pajak langsung adalah pajak yang pembebanannya tidak dapat dialihkan kepihak lain tetapi menjadi beban langsung wajib pajak yang bersangkutan, contoh pajak penghasilan

b.Pajak tidak langsung adalah pajak yang pembebanannya dapat dialihkan kepihak lain, contoh pajak penjualan

2. Menurut Sifat dapat dibagi menjadi :

a.Pajak Subyektif adalah pajak yang berpangkal atau berdasarkan pada subyeknya kemudian dicari syarat obyektifnya, dalam arti memperhatikan keadaan dari wajib pajak. Misalnya pajak penghasilan

b.Pajak Obyektif adalah pajak yang berpangkal atau berdasarkan pada obyeknya tanpa harus memperhatikan keadaan diri wajib pajak. Contoh pajak penjualan barang mewah.

3. Menurut pemungut dan pengelolahnya adalah sebagai berikut : 
a. Pajak Pusat adalah pajak yang dipungut oleh pemerintah pusat dan digunakan umtuk membiayai rumah tangga negara, contonnya pajak Bumi dan Bangunan, pajak bea materai, pajak pengahasilan dan lainnya.

b. Pajak Daerah adalah pajak yang dipungut oleh pemerintah daerah dan digunakan umtuk membiayai rumah tangga daerah, contonnya pajak reklame, pajak hiburan, pajak bumi dan bangunan sektor perkotaan dan pedesaan, pajak perolehan atas tanah dan bangunan (BPHTB)

\subsection{Pengertian Pajak Bumi dan Bangunan}

Menurut Mardiasmo (2011:311) menjelaskan tentang pengertian bumi, bangunan, surat pemberitahuan objek pajak dan Surat pemberitahuan pajak terutang adalah sebagai berikut :

1. Bumi adalah permukaan bumi dan tubuh bumi yang ada dibawahnya. Permukaan bumi meliputi tanah dan perairan pedalaman (termasuk rawa-rawa, tambak, perairan) serta laut wilayah Republik Indonesia.

2. Bangunan adalah konstruksi teknik yang ditanam atau dilekatkan secara tetap pada tanah atau perairan.

3. Surat pemberitahuan objek pajak (SPOP) adalah surat yang digunakan oleh wajib pajak untuk melaporkan data objek menurut ketentuan Undang-Undang pajak dan bangunan.

4. Surat Pemberitahuan Pajak Terutang (SPPT) adalah surat yang digunakan oleh Dirjen Pajak untuk memberitahukan besarnya pajak terutang kepada wajib pajak.

\subsection{Pengertian Nilai Jual Objek Pajak.}

Nilai Jual Objek Pajak (NJOP) adalah harga rata-rata yang diperoleh dari transaksi jual beli yang terjadi secara wajar dan bilamana tidak terdapat transaksi jual NJOP ditentukan melalui perbandingan harga dengan objek lain yang sejenis atau nilai perolehan baru atau nilai jual objek pajak pengganti, menurut Mardiasmo (2011 : 312).

Lebih lanjut dikatakan bahwa Nilai Jual Objek Pajak (NJOP) ditentukan berdasarkan klasifikasi :

1. Objek pajak sektor pedesaan dan perkotaan

2. Objek pajak sektor perkebunan

3. Objek pajak sektor kehutanan atas hak penguasaan hutan, hak pengusahaan hutan dan izin pemanfaatan kayu dan lain sebagainya.

4. Objek pajak sektor kehutanan atas hak pengusahaan hutan tanaman industri.

5. Objek pajak sektor pertambangan minyak dan gas

6. Objek pajak sektor pertambangan energi panas bumi

7. Objek pajak sektor pertambangan non migas selain pertambangan energi panas bumi dan galian $\mathrm{C}$

8. Objek pajak sektor pertambangan non migas galian $\mathrm{C}$

9. Objek pajak sektor pertambangan yang dikelola berdasarkan kontrak karya atau kontrak kerjasama

10. Objek pajak usaha bidang perikanan laut

11. Objek pajak usaha bidang peikanan darat

12. Objek pajak yang bersifat khusus

2.6 Fungsi Pajak secara umum

Mengacu pada Waluyo (2008: 6) terdapat 2 fungsi pajak adalah : 
1. Fungsi Penerimaan (Badgeter) yaitu sumber dana yang diperuntukan bagi pembiayaan pengeluaran-pengeluaran pemerintah, misalnya dimasukkannya pajak dalam APBN sebagai penerimaan dalam negeri

2. Fungsi Mengatur (Reguler), yaitu alat untuk mengatur atau melaksanakan kebijakan dibidang sosial dan ekonomi, misalnya dikenakannya pajak lebih tinggi terhadap minuman keras, dapat ditekan pula terhadap barang mewah.

\subsection{Pengaruh Pajak terhadap Perekonomian}

Menurut Suparmoko (2000:215) mengatakan sistim perpajakan yang terbaik dipandang dari sudut pandangan ilmu ekonomi adalah sistim perpajakan yang memiliki pengaruh-pengaruh ekonomi yang paling baik atau setidak-tidaknya memberikan pengaruh yang paling minimum. Pengaruh pajak terhadap perekonomian ini dapat kita bedakan antaranya pengaruh pajak terhadap produksi dan distribusi dari produksi tersebut dan pengaruh terhadap keinginan untuk bekerja.

Pengaruh pajak terhadap produksi dapat dibagi menjadi 1). pengaruh pajak terhadap produksi secara keseluruhan, 2). Pengaruh pajak terhadap komposisi produksi. Kemudian pengaruh pajak terhadap Distribusi pendapatan, hal ini dapat dilihat bahwa semakin tinggi tingkat pendapatan semakin rendah untuk mengadakan konsumsi tambahan. Dan terakhir pengaruh pajak terhadap keinginan untuk bekerja yaitu dilihat pemberlakuan terhadap pajak progresif yaitu pengaenaan pajaknya semakin tinggi.

\subsection{Daerah dan Waktu Penelitian}

\section{METODE PENELITIAN}

Obyek penelitian dalam penulisan ini adalah Kecamatan Asparaga Kabupaten Gorontalo dan lokasi penelitian ini dipilih karena pertimbangan penghematan biaya. Dan adapun waktu penelitian yang digunakan yakni selama 3 bulan.

\subsection{Definisi Operasional variabel}

Untuk menghindari kesalah fahaman dalam penafsiran terhadap beberapa variabel yang digunakan dalam penelitian ini, maka peneliti memberikan definisi operasional variabel yang menjadi batasan sebagai berikut :

1. Pajak adalah kontribusi kepada negara yang terutang oleh orang pribadi atau badan yang bersifat memaksa berdasarkan UndangUndang, dengan tidak mendapatkan imbalan secara langsung dan digunakan untuk keperluan negara bagi sebesar-besarnya kemakmuran negara.

2. Pajak Bumi dan Bangunan adalah penerimaan pajak yang diperoleh dari sebidang tanah, rawa atau perairan yang diatasnya terdapat konstruksi teknik yang ditanam atau dilekatkan secara tetap pada tanah atau perairan tersebut.

\subsection{Metode Pengumpulan Data}

Metode yang digunakan oleh penulis dalam pengumpulan data adalah sebagai berikut :

3.3.1 Penelitian Kepustakaan (Library research) yaitu mengadakan pengkajian terhadap literatur-literatur yang relevan dengan masalah 
yang dibahas. Hal ini dimaksudkan untuk menunjang dalam proses penganalisaan dalam keperluan konsep-konsep operasionalisasi varabel-variabel analisis.

3.3.2 Penelitian lapangan (Field research) yang merupakan penelitian langsung ke obyek penelitian melalui teknik pengumpulan data sebagai berikut :

1.Observasi yaitu dengan mengamati dan meneliti segala sesuatu yang ada hubungannya dengan penelitian.

2. Wawancara yaitu mengadakan wawancara langsung kepada pihak kantor Dinas terkait yang berhubungan dengan obyek penelitian.

3.Dokumentasi yaitu mengadakan pencatatan dokumen dan informasi yang berkaitan dengan obyek penelitian tersebut.

\subsection{Jenis dan Sumber Data}

\subsubsection{Jenis Data}

1. Data Kuantitatif yaitu merupakan data (dinyatakan dalam angkaangka) yang diperoleh dari hasil olahan data primer dan data sekunder

2. Data Kualitatif yaitu data yang tidak dihitung atau bukan berupa angka-angka tetapi berupa kalimat-kalimat yang diperoleh dari hasil wawancara melalui kuisioner dengan berbagai pihak.

\subsubsection{Sumber data}

1. Data Primer, merupakan data yang diperoleh langsung dari obyek penelitian baik melalui wawancara maupun dari hasil pengamatan (observasi) pada masyarakat wajib pajak Bumi dan Bangunan di Kecamatan Asparaga Kabupaten Gorontalo.

2. Data sekunder yaitu data yang bersumber dari dokumen-dokumen yang ada di instansi terkait yang ada dalam wilayah Kecamatan Asparaga Kabupaten Gorontalo.

\subsection{Metode Analisis}

Dalam penelitian ini akan digunakan metode analisis sebagai berikut :

3.5.1 Metode analisis Kualitatif

Dalam hal ini akan dipaparkan berdasarkan analisis kondisi objektif dan temuan-temuan yang dihubungkan dengan teori-teori ilmiah, sehingga diperoleh gambaran secara sistimatis, faktual dan aktual serta solusi-solusi terhadap pemecahannya.

3.5.2 Metode analisis Kuantitatif

Metode ini digunakan dengan cara menggambarkan perkembangan penerimaan Pajak Bumi dan Bangunan di Kecamatan Asparaga Kabupaten Gorontalo pada setiap tahun. Adapun metode analisis yang digunakan yaitu metode analisa trend linier sebagaimana dikemukakan, Supranto (2001 : 57) sebagai berikut:

$$
\mathbf{Y}=\mathbf{a}+\mathbf{b X}
$$

Dimana :

$\mathrm{Y}=$ Jumlah Penerimaan Pajak Bumi dan Bangunan (Rupiah)

$\mathrm{X} \quad=$ Periode Waktu

a $\quad=$ Konstanta dalam Persamaan Trend

$\mathrm{b} \quad=$ Tingkat Kecendrungan 


$$
\text { dimana } a=\frac{\Sigma Y}{n} \text { dan } b=\frac{\Sigma X Y}{X^{2}}
$$

\section{HASIL PENELITIAN DAN PEMBAHASAN}

\subsection{Deskripsi Variabel Penelitian}

Kecamatan Asparaga merupakan salah satu kecamatan yang ada di Kabupaten Gorontalo yang sejak dibentuk telah melakukan berbagai kegiatan pelayanan pemerintahannya secara terpadu dan terintegral dengan dibantu seluruh kepala-kepala desa dilingkungan sekitarnya. Dengan demikian segala tuntutan dan pengaduan serta kewajiban yang melekat pada seluruh warga negaranya selalu terkordinasi dengan baik melalui pihak kecamatan serta perangkatnya sehingga upaya pemerintah daerah selalu memperhatikan dan membantu sesuai dengan yang disumbangkan oleh masing-masing kecamatan yang ada terutama peningkatan fasilitas pelayanan, peningkatan jalan, jembatan serta berbagai bentuk pembangunan yang memang benarbenar dibutuhkan masyarakat selalu terpenuhi seperti kecamatan lainnya.

Memperhatikan bentuk pemerintah daerah maupun pemerintah kecamatan cukup memuaskan bagi seluruh masyarakat Kecamatan Asparaga sehingga masyarakat secara keseluruhan pula selalu mendukung sepenuhnya segala tuntutan dan kewajiban mereka berupa pembayaran pajak bumi dan bangunan dan hampir keseluruhan penduduk menjadi objek pajak tersebut karena telah memiliki lahan dan pemukiman yang syah dan bersama keluarga mereka secara berturut-turut karena telah mendapatkan bagian warisan kekayaan mereka sehingga mereka inilah yang menambah jumlah objek pada setiap tahunnya.

Untuk itu, dengan data yang telah dikumpulkan dari berbagai pihak seperti data penduduk, data sumberdaya alam, data sumber kepemilikan lahan dan lain sebagainya yang tercatat terlebih dahulu pada masing-masing desa kemudian dilimpahkan ke Kecamatan sehingga pihak kecamatan mengumpulkannya dalam Daftar Himpunan Penetapan dan Pembayaran (DHKP) diKecamatan yang bersangkutan pada setiap tahunnya.

Berdasarkan Daftar Himpunan Penetapan dan Pembayaran (DHKP) Kecamatan Asparaga diperoleh gambaran Jumlah penerimaan Pajak Bumi dan Bangunan untuk tahun 2012 - 2016 adalah sebagai berikut :

Tabel 4. Jumlah Penerimaan

Pajak Bumi dan Bangunan Kecamatan Asparaga tahun 2012-2016

\begin{tabular}{|l|l|l|c|}
\hline No & Tahun & Jumlah PBB & Pertumbuhan \\
\hline 1 & 2012 & 81.675 .045 & - \\
2 & 2013 & 85.114 .017 & $4,00 \%$ \\
3 & 2014 & 85.310 .854 & $0,23 \%$ \\
4 & 2015 & 98.708 .879 & $13,57 \%$ \\
5 & 2016 & 99.909 .778 & $1,20 \%$ \\
\hline
\end{tabular}

Sumber Data, Daftar Himpunan Ketetapan dan

Pembayaran PBB Kec.Asparaga tahun 2012-2016

Berdasarkan tabel tersebut dapat dijelaskan bahwa Pajak Bumi dan Bangunan dari tahun 2012 ke tahun 2013 mengalami pertumbuhan sebesar 4,00 \% \%, Pajak Bumi dan Bangunan dari tahun 2013 ke tahun 2014 mengalami pertumbuhan sebesar 0,23\%, Pajak Bumi dan Bangunan dari tahun 2014 ke tahun 2015 mengalami pertumbuhan sebesar 13,57\%, Pajak 
Bumi dan Bangunan dari tahun 2015 ke tahun 2016 mengalami pertumbuhan sebesar 1,20\%. Hal ini dapat terjadi karena berkembangnya wajib objek pajak dikalangan masyarakat yang telah memiliki lahan sebelumnya kemudian terjadi perubahan status lahan mereka karena pemecahan lahan karena pembagian warisan, jual beli dan pendirian bangunan disetiap lahan sehingga penetapan objek pajak akan berubah atau dari faktor lainnya berupa penetapan beban objek pajak yang baru oleh pemerintah pada tahun tersebut.

Berdasarkan data pada tabel tersebut, kemudian akan dianalisa lebih lanjut dengan menggunakan analisa Trend Linier sehingga pertumbuhannya dapat diketahui sehingga mempermudah pemerintah menetapkan kebijakan selanjutnya.

Untuk memahami dan mengetahui perkembangan Pajak Bumi dan Bangunan pada Kecamatan Asparaga dari seluruh Desa yang ada maka melalui penelitian ini akan dijelaskan lebih lanjut sehingga dapat diketahui perkembangan secara jelas dan akurat pada obyek penelitian yang diteliti dengan menggunakan analisa Trend Linier adalah sebagai berikut :

Berdasarkan pada tabel 4 sebelumnya maka dapat dihitung trend linier untuk Penerimaan PBB dari tahun 2012-2016 dengan dibantu menggunakan program SPSS adalah sebagai berikut:

Tabel 5. Tabulasi perhitungan trend linier

\begin{tabular}{|c|l|l|l|l|l|}
\hline No Urt & X & Y & XY & $X^{2}$ & N \\
\hline 1 & -2 & 81675045 & -163350090 & 4 & \\
2 & -1 & 85114017 & -85114017 & 1 & \\
3 & 0 & 85310854 & 0 & 0 & 5 \\
4 & 1 & 98708879 & 98708879 & 1 & \\
5 & 2 & 99909778 & 199819556 & 4 & \\
\hline Jumlah & 0 & 450718573 & 50064328 & 10 & \\
\hline
\end{tabular}

Sumber data, Hasil Olahan, 2016

Dalan uraian ini akan digunakan analisa trend linier sebagai berikut :

$\mathrm{Y}=\mathrm{a}+\mathrm{bX}$ Artinya adalah :

$\mathrm{Y}=$ Jumlah penerimaan PBB Kecamatan Asparaga (Rupiah)

$\mathrm{X} \quad=$ Periode Waktu

dimana $\mathrm{a}=\frac{\Sigma \mathrm{Y}}{\mathrm{n}}$ dan $\mathrm{b}=\frac{\Sigma \mathrm{XY}}{\mathrm{X}^{2}}$

Selanjutnya dengan menggunakan program SPSS (Statistical Product Service Solution) dan dengan berdasarkan data yang ada maka dapat diperoleh persamaan $\mathrm{Y}=90143714.600+0,931 \mathrm{X}$ dengan angka signifikan 0,021 yang berarti keterpengaruhannya sangat besar pada peningkatan PBB di Kecamatan Asparaga.

Dengan demikian berdasarkan perhitungan yang menggunakan analisa Trend Linier tersebut maka dapat diperoleh persamaannya adalah $\mathrm{Y}=$ $90143714.600+0,931 \mathrm{X}$, sehingga selanjutnya dapat diprediksi trend penerimaan untuk prospek 5 tahun kedepan penerimaan PPB di Kecamatan Asparaga adalah sebagai berikut :

1. Untuk tahun 2017

Apabila $\mathrm{X}=3$ maka $\mathrm{Y}$ realisasi penerimaan $\mathrm{PBB}$ yang dapat diperoleh adalah: 
$\mathrm{Y} 2017(3) \quad=90143714.600+0,931$ (3)

$$
=90143714.600+2,793=90143717.393
$$

2. Untuk tahun 2018

Apabila $X=4$ maka $Y$ realisasi penerimaan PBB yang dapat diperoleh adalah:

$\mathrm{Y} 2017(4) \quad=90143714.600+0,931$ (4)

$$
=90143714.600+3,724=90143718,324
$$

3. Untuk tahun 2019

Apabila $\mathrm{X}=5$ maka $\mathrm{Y}$ realisasi penerimaan $\mathrm{PBB}$ yang dapat diperoleh adalah:

$$
\begin{aligned}
& \mathrm{Y} 2020(5) \quad=90143714.600+0,931 \text { (5) } \\
& =90143714.600+4,655=90143719,255
\end{aligned}
$$

4. Untuk tahun 2020

Apabila $X=6$ maka $Y$ realisasi penerimaan PBB yang dapat diperoleh adalah:

$$
\begin{aligned}
\mathrm{Y} 2020(6) \quad & =90143714.600+0,931(6) \\
& =90143714.600+5,586=90143720,186
\end{aligned}
$$

5. Untuk tahun 2021

Apabila $\mathrm{X}=7$ maka $\mathrm{Y}$ realisasi penerimaan $\mathrm{PBB}$ yang dapat diperoleh adalah:

$$
\begin{aligned}
& \mathrm{Y} 2020(7) \quad=90143714.600+0,931 \text { (7) } \\
& =90143714.600+6,517=90143721,117
\end{aligned}
$$

Dengan berdasarkan perhitungan trend linier tentang realisasi penerimaan PBB maka berikut dapat digambarkan berapa perkiraan penerimaan realisasi penerimaan PBB tersebut pada tahun 2017 sampai dengan tahun 2021 adalah sebagai berikut :

Tabel 6. Prospek realisasi penerimaan PBB tahun 2017-2021

\begin{tabular}{|l|l|c|c|}
\hline No & Tahun & $\begin{array}{c}\text { Jumlah } \\
\text { Realisasi PBB }\end{array}$ & $\begin{array}{c}\text { Prosentase } \\
\text { Pertumbuhan }\end{array}$ \\
\hline 1 & 2017 & 90143717.393 & - \\
2 & 2018 & 90143718,324 & 99,99 \\
3 & 2019 & 90143719,255 & 99,99 \\
4 & 2020 & 90143720,186 & 9,99 \\
5 & 2021 & 90143721,117 & 9,99 \\
\hline
\end{tabular}

Sumber data : Hasil Olahan tahun 2017

Dengan melihat trend linier tersebut maka jumlah penerimaan PBB pada setiap tahun akan berkembang dan terus meningkat untuk tahun 2017-2021. karena berdasarkan kajian tersebut diatas menggambarkan adanya jumlah potensi peningkatan penerimaan PBB dari tahun ketahun semakin meningkat terus yang memberikan gambaran yang nyata pada jumlah peningkatan kesejahtraan masyarakat desa pada setiap rumah tangga pada tahun-tahun akan datang, Sehingga hipotesa yang diajukan terbukti.

Untuk mempermudah melihat gambaran perkembangan jumlah penerimaan PBB dari tahun 2012-2016 dan perkembangan peningkatan 
jumlah penerimaan PBB 5 tahun kedepan dari tahun 2017-2021 maka berikut ini akan ditunjukkan pada tabel berikut :

Tabel 7. Keadaan pertumbuhan penerimaan PBB dari tahun 2012-2016 dan

jumlah estimasi penerimaan PBB dari tahun 2017-2021

\begin{tabular}{|c|c|c|c|}
\hline No & Tahun & $\begin{array}{c}\text { Jumlah } \\
\text { penerimaan PBB }(\mathrm{Rp})\end{array}$ & $\begin{array}{c}\text { Prosentase } \\
\text { Pertumbuhan(\%) }\end{array}$ \\
\hline 1 & 2012 & 81.675 .045 & - \\
2 & 2013 & 85.114 .017 & 95,96 \\
3 & 2014 & 85.310 .854 & 99,77 \\
4 & 2015 & 98.708 .879 & 86,43 \\
5 & 2016 & 99.909 .778 & 98,80 \\
6 & 2017 & 90.143 .717 & 99,99 \\
7 & 2018 & 90.143 .718 & 99,99 \\
8 & 2019 & 90.143 .719 & 9,99 \\
9 & 2020 & 90.143 .720 & 9,99 \\
10 & 2021 & 90.143 .721 & - \\
\hline
\end{tabular}

Sumber Data, Hasil Olahan Penelitian 2017

Dengan memperhatikan pertumbuhan Penerimaan PBB di Kecamatan Asparaga pada tabel diatas memberikan gambaran bahwa periode tahun 2012-2016 merupakan peristiwa atau informasi yang terjadi dan dijadikan sebagai prediksi untuk perkembangan PBB untuk periode 2017-2021 sehingga menghasilkan gambaran trend perkembangannya yang semakin meningkat sehingga hal ini akan memberikan kepastian dalam melahirkan kebijakan oleh pemerintah tentang upaya yang akan dilakukan kepada masyarakat dalam hal menidentifikasi kembali berbagai jenis lahan kepemilikan yang belum dipisahkan atau kegiatan jual beli diantara masyarakat yang belum dilakukan pengukuran lahan apabila dipisahkan dari yang sebelumnya atau perlunya penetapan nilai NJOP yang baru sehingga dapat merubah secara otomatis pada jumlah PPB yang akan dibayarkan.

Dengan demikian telah diperoleh informasi tentang perkembangan jumlah penerimaan PBB yang ada di Kecamatan Asparaga pada setiap tahunnya yang menunjukkan rata-rata perkembangannya meningkat setiap tahunnya. Dengan demikian segala yang terkait dengan potensi yang dapat meningkatkan jumlah penerimaan PBB tersebut harus lebih diidentifikasi kembali sehingga dapat diketahui potensi yang memberikan penerimaan PBB di tahun akan datang.

\subsection{Pembahasan Penelitian}

Penerimaan PBB pada suatu kecamatan tertentu merupakan keseluruhan sumber pendapatan yang diterima dan dijadikan sebagai bentuk penganggaran bagi daerah dalam melakukan pembangunan yang direncanakan karena semata-mata Anggaran Pendapatan Belanja Kecamatan bersumber dari penerimaan PBB tersebut. Untuk itu dalam upaya peningkatan penerimaan $\mathrm{PBB}$ haruslah dilakukan segiat-giatnya agar target penerimaan tersebut dapat dicapai atau terealisasi sebagaimana mestinya.

Dengan demikian telah diperoleh informasi tentang perkembangan jumlah penerimaan PBB yang ada di Kecamatan Asparaga pada setiap tahunnya yang menunjukkan rata-rata perkembangannya meningkat setiap tahunnya. Untuk itu segala yang terkait dengan potensi yang dapat 
meningkatkan jumlah penerimaan PBB tersebut harus lebih diidentifikasi jenis maupun bentuk pengelolaan potensi sehingga dapat memberikan upaya peningkatan penerimaan PBB di tahun akan datang.

Kemudian dari jumlah penerimaan PBB tersebut telah diperoleh pula informasi tentang jumlah penerimaan PBB pada tahun akan datang yakni dari tahun 2017-2021 dengan nilai rata-rata yang terjadi adalah meningkat pertahun, sehingga penerimaan $\mathrm{PBB}$ tersebut sangat dirasakan semakin meningkat seiring dengan berkembangnya jumlah peningkatan pembangunan di Kecamatan tersebut pada setiap tahun nanti.

Kemudian dengan data jumlah penerimaan PBB tersebut dapat dilakukan pengujiannya secara trend linier secara berurutan pada setiap tahunnya sehingga diperoleh nilai trend liniernya adalah sebagai berikut : $\mathrm{Y}=$ $90143714.600+0,931 \quad X$ dimana apabila $X$ dalam keadaan konstan maka penerimaan $\mathrm{PBB}$ akan terjadi sedemikian rupa pada setiap tahun sehingga diperoleh nilai estimasi atau perkiraan penerimaan PBB pada tahun-tahun akan datang.

Kalau dihubungkan dengan hasil Penelitian menurut Sri Mesrawaty Katili (2013) dengan judul "Pengaruh Nilai Jual Objek Pajak terhadap penerimaan pajak Bumi dan bangunan di Desa Leboto Kecamatan Kwandang Kabupaten Gorontalo Utara" Penelitian ini bertujuan untuk mengetahui pengaruh nilai jual objek pajak terhadap penerimaan pajak bumi dan bangunan di Desa Leboto Kecamatan Kwandang Kabupaten Gorontalo Utara.

Dengan hasil penelitian yang diperoleh Persamaan Regresi sederhana adalah :

$\mathrm{Y}=-1089552,745+2585,244 \mathrm{X}$ sehingga dapat dijelaskan adalah :

- Keefisien a $=-1089552,745$; artinya bahwa dalam keadaan konstan atau tidak ada perkembangan jumlah objek pajak maka besarnya penerimaan jumlah pajak PBB di Desa Leboto Kecamatan Kwandang Kabupaten Gorontalo Utara adalah sebesar -1089552,745

- Koefisien $b=2585,244$; artinya setiap adanya perkembangan jumlah objek pajak maka penerimaan jumlah pajak PBB di Desa Leboto Kecamatan Kwandang Kabupaten Gorontalo Utara meningkat sebesar 2585,244 atau $25,85 \%$ dari semula dengan asumsi faktor lain konstan.

Kemudian Nilai korelasi (R) adalah 0,969, artinya perkembangan jumlah objek pajak memiliki pengaruh yang kuat positif terhadap penerimaan jumlah pajak PBB dan koefisien determinasi $R$ Square $\left(R^{2}\right)$ sebesar 0,938, jadi kontribusi perkembangan jumlah objek pajak terhadap peneimaan jumlah pajak PBB adalah sebesar 93,8 \% sedangkan 6,2\% dipengaruhi oleh faktor lain yang tidak dihitung.

Perbedaan dengan penelitian ini terletak pada unit analisis penelitian dimana penelitian sebelumnya hanya melihat pada Pengaruh Nilai Jual Objek Pajak terhadap penerimaan pajak Bumi dan bangunan di Desa Leboto Kecamatan Kwandang Kabupaten Gorontalo Utara, sedangkan penelitian ini mengangkat masalah gambaran prospek penerimaan PBB di Kecamatan Asparaga Kabupaten Gorontalo pada setiap tahunnya sehingga dapat diketahui upaya pengembangan potensi obyek pajak tersebut kedepan.

\section{SIMPULAN DAN SARAN}

\subsection{Simpulan}

Berdasarkan analisa dan uraian dalam bab-bab sebelumnya maka penulis dapat menarik simpulan sebagai berikut : 
1. Dengan berdasarkan hasil penelitian tersebut telah menunjukkan perkembangan jumlah penerimaan PBB semakin meningkat di Kecamatan Asparaga mulai tahun 2012-2016 sehingga ditahun akan datang diharapkan supaya semua potensi yang dapat meningkatkan penerimaan PBB tersebut dapat digali dan dimanfaatkan semaksimal mungkin agar apa yang diusahakan dapat tercapai sesuai yang diinginkan.

2. Dengan melihat perkembangan tuntutan pembangunan fasilitas ekonomi masyarakat maka hal ini harus dibarengi dengan meningkatnya jumlah penerimaan PBB pada setiap tahun sebagaimana pada informasi tahun 2012-2016 di Kecamatan Asparaga, semakin meningkat dengan nilai Trend Liniernya adalah $\mathrm{Y}=90143714.600+0,931 \mathrm{X}$ sehingga dengan menggunakan analisa trend linier tersebut maka jumlah estimasi yang terjadi antara tahun 2017-2021 tentang jumlah penerimaan PBB telah menunjukkan peningkatan pula pada setiap periode tersebut.

3. Dengan melihat tingkat perkembangan yang nampak pada setiap periode tersebut tentang penerimaan PBB dari berbagai jenis sumber penerimaan yang ada di Kecamatan Asparaga maka untuk perkembangan penerimaan PBB ditahun akan datang harus dipertahankan oleh pemerintah Kecamatan dan bersama masyarakat sehingga faktor pertumbuhan ekonomi pula semakin meningkat dimasa akan datang.

\subsection{Saran}

1. Dengan dibuktikannya hasil penelitian ini telah melahirkan bentuk penguatan struktur ekonomi yang perlu ditingkatkan serta upaya kebijakan pemerintah dalam meningkatkan fasilitas pelayanan kebutuhan publik kepada masyarakat sebagai pengguna jasa sehingga akan lebih mendorong masyarakat untuk termotivasi meningkatkan berbagai jenis aktifitas ekonomi guna merangsang meningkatnya PBB tersebut pada setiap tahun.

2. Bahwa dengan melihat perkembangan penerimaan PBB dari tahun ketahun semakin meningkat maka perlu sosialisasi kepada masyarakat akan ditingkatkan sehingga tingkat pemahaman masyarakat sebagai anggota masyarakat menjadi melekat dalam arti bahwa segala pembangunan yang dilaksanakan semata-mata pembiayaannya dari rakyat akan kembali kepada rakyat dalam bentuk peningkatan fasilitas seperti jalan, sekolah dan lain sebagainya.

3. Dengan dibuktikannya hasil penelitian ini dengan menggunakan terd linier maka hal ini perlu dipertahankan kalau perlu ditingkatkan ditahun akan datang sehingga perencanaan pembangunan desa yang dicanangkan setiap tahun dapat tercapai dan terselenggara dengan baik tanpa ada penundaan kegiatan yang terjadi nanti.

\section{REFERENSI}

Arsyad, Lincolin, 2000, Pengantar Perencanaan dan Pembangunan Daerah, edisi pertama, penerbit BPFE, Yogyakarta.

Bangun, Wilson, 2007, Teori Ekonomi Mikro, Penerbit Refika Aditama, Bandung

Badudu, J. S, 2001, Kamus Umum Indonesia, Penerbit Jakarta

Darise, Nurlan, 2006, Pengelolaan Keuangan Daerah, Penerbit PT Index Kolompok Gramedia, Jakarta 
Jhingan, ML, 2003, Ekonomi Pembangunan dan Penencanaan, Penerbit PT Grafindo Persada, Jakarta

Halim, Abdul, 2007, Pengelolaan Keuangan Daerah, Penerbit UPP Stim YKPN, Yokyakarta

Koku, Insar, 2012, prospek penerimaan Pajak Kendraan Bermotor di Provinsi Gorontalo, Sktipsi Fakultas Ekonomi Universitas Gorontalo.

Kaharu, Usman, 2004, Ekonomi Pembangunan, Penerbit Nurul Jannah, Gorontalo

Krugman, R Paul, 2003, Pengertian Prospek pada http:/ / taqinpanteraya.blogpot.co.id/ 2010/10/html yang dikutif tanggal 2 Desember 2016

Rahardja, Pratama dkk ( 2010 : 1), Teori Ekonomi Mikro, suatu pengantar, Penerbit Fakultas Ekonomi, Universitas Indonesia, Jakarta

Sanusi, Buchrawi, 2004, Pengantar ekonomi Pembangunan, Penerbit Rineke Cipta, Jakarta

Sukirno, Sadono, 2003, Ekonomi Pembangunan,Proses Masaalah dan Dasar Kebijaksanaan, Penerbit Fakultas Ekonomi, Penerbit Universitas Indonesia, Jakarta

Suparmoko, M, 2003, Ekonomi Pembangunan, Penerbit UPP AMP YKPN, Yokyakarta

Trihartono, Bambang dkk, 2004, Kekuasaan Penegelolaan Keuangan Negara / Daerah, Penerbit Gramedia, Jakarta. 